\title{
OHS Information System (Occupational Health and Safety) In PT. United Tractors Tbk, Site-Satui Mobile Web-Based
}

\author{
Maya Gian Sister ${ }^{1, *}$, Agustian Noor ${ }^{2}$, Khairul Anwar Hafizd ${ }^{3}$ \\ 1,2,3 Department of Information Technology, Politeknik Negeri Tanah Laut, Indonesia
}

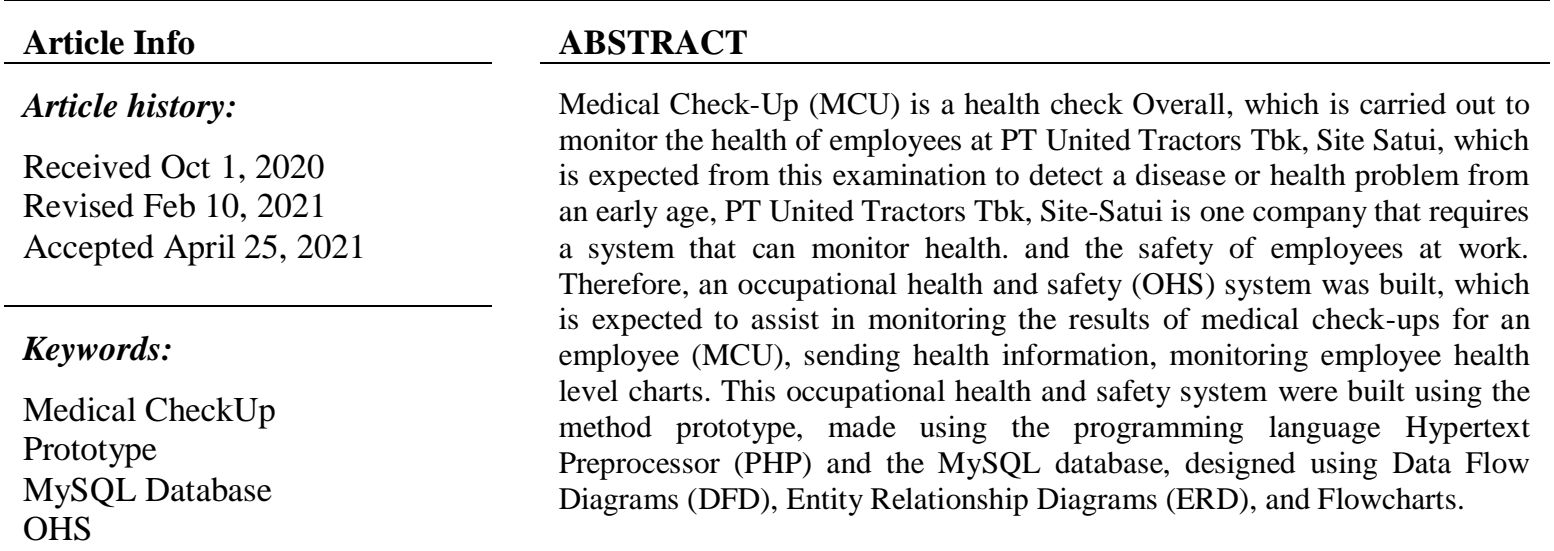

This is an open-access article under the CC BY-SA license.

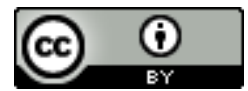

\section{Corresponding Author:}

Maya Gian Sister,

Information Technology,

Politeknik Negeri Tanah Laut,

Jl. A. Yani KM.6, Panggung, Pelaihari, Tanah Laut, Kalimantan Selatan, Indonesia, 70815.

Email: mayagiansister@gmail.com

\section{INTRODUCTION}

Entering the industrial era 4.0 makes the internet a giant network that is used as a link between computers to computers to smartphones in the same network, where technology in this era is developing rapidly in accessing information and being able to record everything within 24 hours a day. So that there are so many various groups who take advantage of current technology to simplify and increase factory productivity which was not thought of to be a very good idea. Like many companies to create a new formula, in the form of an application which is expected to help make work easier and faster. One of them is PT United Tractors Tbk, Site-Satui.

PT United Tractors Tbk, Site-Satui is a company engaged in the service of heavy equipment and the supply of spare parts, which is part of Astra International based in Jakarta. PT United Tractors Tbk, Site-Satui has several subcontractors that are spread out, such as PT Livan Karya, KAMAJU, GSI, TRAC, 99 Motor, and others. PT United Tractors Tbk, Site-Satui is divided into several areas, namely Sungai Danau, Satui, Kusan, Giri Mulya, and Batu Licin, with 3 departments namely Department of Administration, Department, of Spare, and Department of Service.

The three departments at PT United Tractors, Tbk Site-Satui, have their respective employees, who are required to have a health check or MCU. This medical check-up (MCU) is intended so that employees can find out about each other's health so that if there is one employee who is not currently experiencing health 
problems or is not fit at work, he can be given a warning about his health. The importance of employee health in working at PT United Tractors, Tbk Site-Satui is very important, to reduce the risk of work accidents.

The importance of occupational health and safety is often conveyed during Safety Talk and Healthy Talk activities every week at PT United Tractors, Tbk Site-Satui, to remind employees about the importance of health and safety at work [1]. But even so, sometimes there are still people who forget to pay attention to health at work [2], which can cause an undesirable event that will harm employees and the company. The health of each employee at PT United Tractors, Tbk Site-Satui is recorded in a file and stored in a box, sometimes some are scattered in the sense that there is a missing record file Medical Check-Up (MCU) [3] so that the employee cannot see the results of his examination, sometimes there are employees who ignore the results of the examination so that when they are asked for their medical records, they will be confused. Health records that are still conventional, in the sense that they are still written on paper and the personal reports of each employee are what makes it difficult for the next examination Medical Check-Up (MCU), with a large number of employees and the absence of specialized personnel to handle it, so it occurs an increase in the number of follow-up Medical Check-Up (MCU) that are not monitored and documented.

The increasing number of follow-up Medical Check-Up (MCU) which continues to increase causes an uncontrolled notification to employees who have special records, and there is no routine notification of health to employees, which causes frequent employee negligence in carrying out further examinations, and the absence of health status which is written also, the next factor is employees who are too busy at work, so that employees cannot control their health without waiting for notification from the boss [1]. The current problem is that no system controls the health of employees, so this is what causes the level of the number of follow-up Medical Check-Ups (MCU) to continue to increase and not be controlled or documented routinely.

The solution to the problem that occurs is to create an information system about the health and safety of employees so that in the future it can assist in health monitoring, reminders, sending notifications, and displaying the health statistics of each employee who works. Based on these problems, the authors raised the title "Information Systems OHS (Occupational Health and Safety) at PT United Tractors, Tbk Site Satui based on Mobile Web" as research in completing the final project.

\section{THEORETICAL}

\subsection{Information Systems Information}

Systems are a combination of components or rules in which there is data that is processed whether it is collecting, modifying, or disseminating information to an organization, which can be accessed with a free place and time in an unspecified sense [4].

\subsection{OHS (Occupational Safety and Health)}

Occupational Health Safety is the smooth running of an activity that greatly affects the level of safety and comfort of a working environment [5] and is also supported by equipment that is fit for use and does not endanger workers.

\subsection{Mobile}

Web The mobile web is a web page that is accessed on a device mobile with a small physical build and is made with PHP and Javascript scripts, as for the example of the Mobile Web is an application whose user interface can be made consistent for all devices (multiplatform), does not depend on the play store or app store, and can be opened almost in all types of browsers found on all platforms [6].

\subsection{Entity Relationship Diagram (ERD)}

Entity Relationship Diagram (ERD) is a diagram used for design database on requirements indevelopment system that includes detailed descriptions of entities, relationships, and boundaries, there are several cardinalities, namely one-to-one, one-to-many, and many-to-many [7].

\subsection{Data Flow Diagrams (DFD)}

Data Flow Diagrams (DFD) is a data logic model or process created to describe where the data comes from and where the data output from the system is, where the data is stored [8], what process produces the data, and the interaction between the stored data and the processes imposed on the data [9]. 


\subsection{Blackbox}

Testing black-box is software testing the activity of the specific terms of the functionality of the system created and performed by creating a test case that has the nature to try all the existing functionality within the system following the necessary specific [7].

\section{RESEARCH METHOD}

\subsection{Stage Data Collection}

There are also data collection stages, including the following:

\section{a. The Book Method}

The method that uses books and literature other such as reading books, journals, articles, and other sites in writing that can help the application development process is done by collecting data and information that can be justified for the correctness of the data, so the authors use this method [4].

\section{b. The Interview Methode}

The method is a method of collecting data by conducting questions and answers with employees [10] at PT United Tractors Tbk, Site-Satui, to obtain data and information that supports the making of applications and reports from the OHS Information System (Occupational Health and Safety) at PT United Tractors Tbk, Site-Satui.

\subsection{Development}

The model development that the author uses is Prototype, whose stages can be seen in the image below.

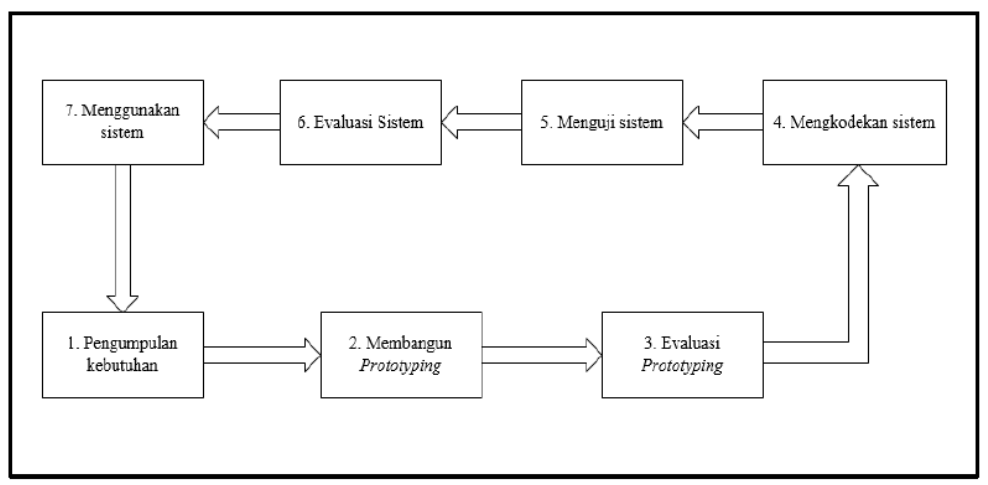

Figure 1. The system development model the prototype

Following figure 1 is an explanation of the stages in the Development Process in the Model Prototype [10], in the image above, namely:

1. Collection of needs: At this stage, the author discusses with the field supervisor the needs needed in developing the application to be made.

2. Building Prototyping: At this stage, the writer makes a design of the application display which will be used as a display application that is made.

3. Evaluation: At this stage, the writer submits the design results of the display design to the company to see whether it is appropriate or not.

4. Encoding: At this stage, the author is carried out after the results of the display design have been agreed upon by the company, which then the authors do the coding system.

5. System Testing: At this stage, the author is carried out after the coding of the system has been completed which is then tested by several parties from employees at PT United Tractors Tbk, Site Satui, including for employee users, officers, and admin by holding meetings, as a method. Blackbox and the response time are done by opening the application at the same time. 
6. System Evaluation: At this stage the writer evaluates the application after testing the system and analyzes the errors or errors that occur in the application, this stage is very important for the smooth running of the application.

7. System Usage: Software that customers have tested and accepted is ready for use. This stage is carried out after the system is running and system maintenance is carried out.

\section{RESULTS AND DISCUSSION}

\subsection{System Analysis}

\section{a. Current System Analysis}

In the current system, the officer will first manage the results of the employees' MCU which will be stored or archived in a Bantex. Furthermore, for employees who will see the results of their MCU, each them will ask the officer, at the next stage the officer will notify reminder messages and tips about health in a conventional way through group chat or sometimes written on an announcement board located in the room the service office, and then the next stage the employee will receive the results of the MCU records in paper form and if there is a further inspection, the employee will submit the results to the officer for safekeeping [7].

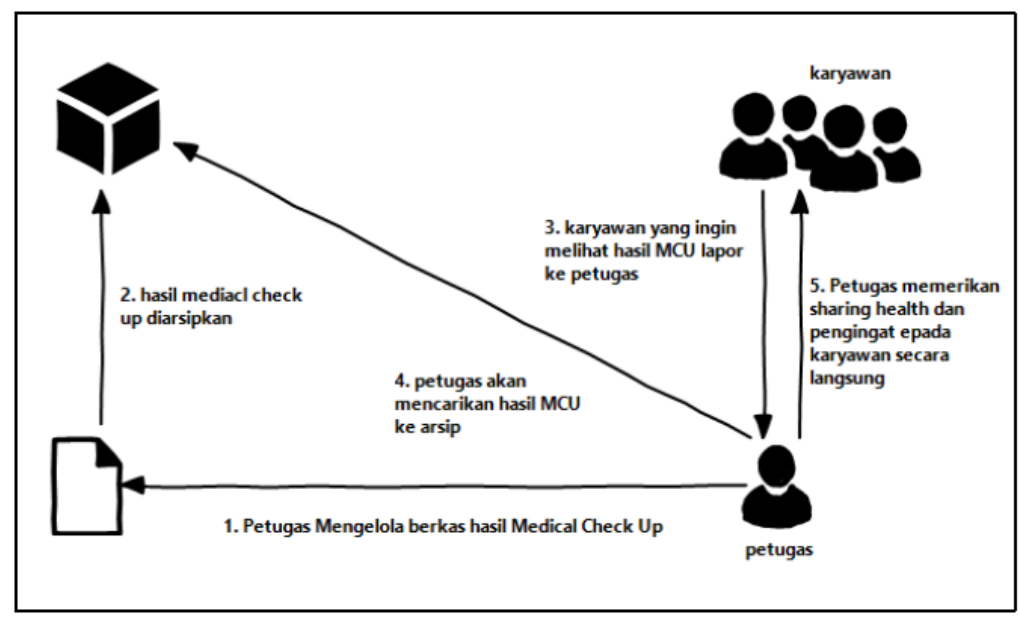

Figure 2. Analysis of the running system

\section{b. Analysis of The Proposed System}

In the Analysis of the Proposed System, data on the results of Medical Check-Up will be entered into the system, so that it can help employees who want to see the results of the MCU only through the system without having to report to the officer first, and also if there is Sharing Health or reminder messages officers do not need to notify employees one by one but through the system [7].

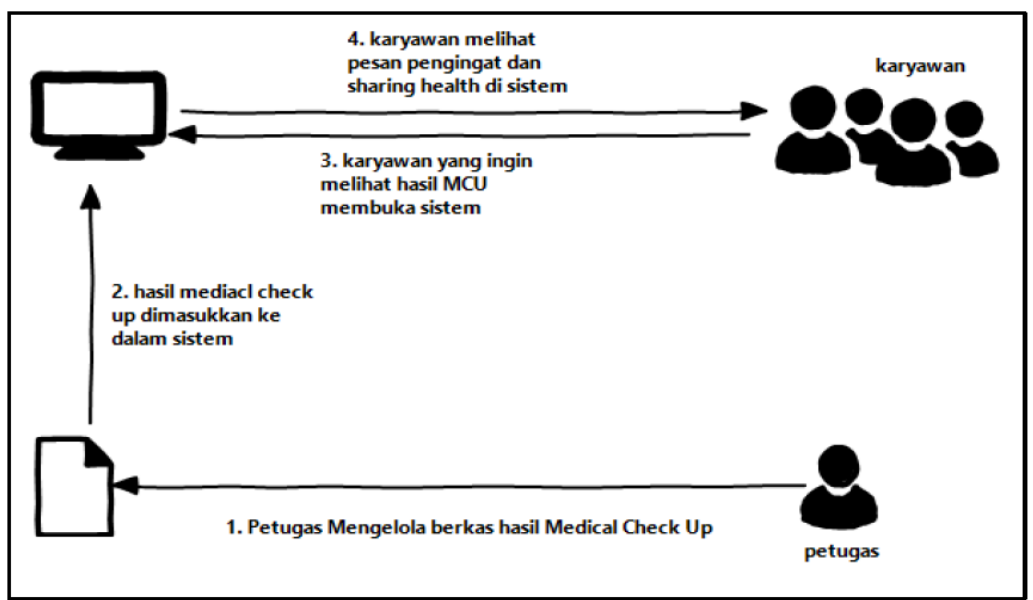

International Journal of Research in Vocational Studies, Vol. 1, No. 1, September 2021: 01 - 10 
Figure 3. Analysis of the proposed system

\subsection{System Design}

\section{a. Entity Relationship Diagram (ERD)}

The design of the Entity-Relationship Diagram has 12 entities, namely accounts, access, area, area depart, department, Medical, standards, type Medical, conclusion, position, employee type, sharing, and reminder. Employee entity is a master table related to all entities [11].

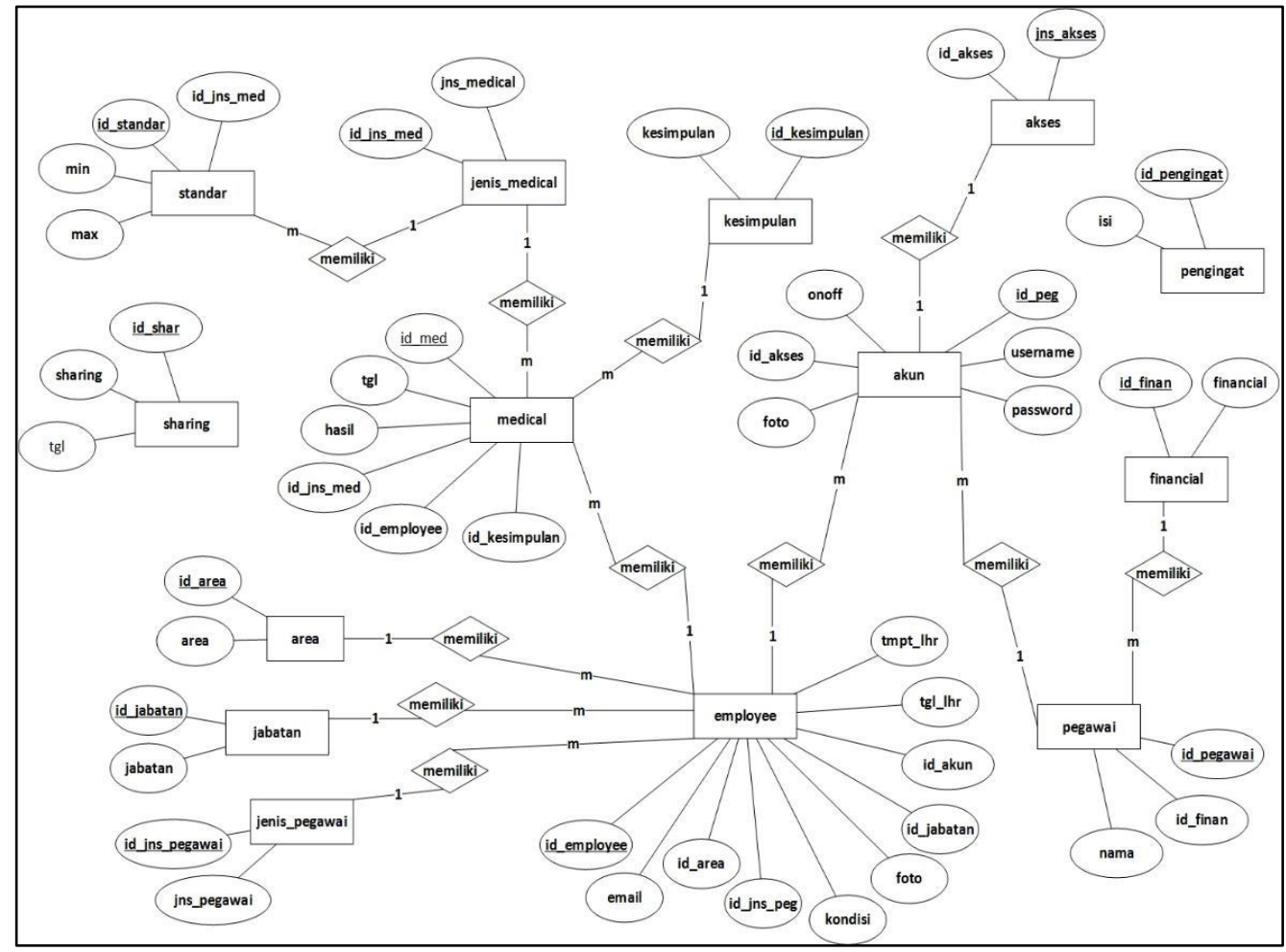

Figure 4. Entity Relationship Diagram (ERD)

\section{b. Context Diagram}

Figure 5 is a context diagram with an explanation that Admin can manage, Login data Medical, data, graphic data, employee data, reminder data, conclusion datatype data Medical, standard data Medical, employee type data, and data sharing. Officers can manage data login, data Medical, graphic data, employee data, reminder data, sharing data, and employee type data. Employees can manage login data medical, data, reminder data, sharing data, and graph data [12]. 


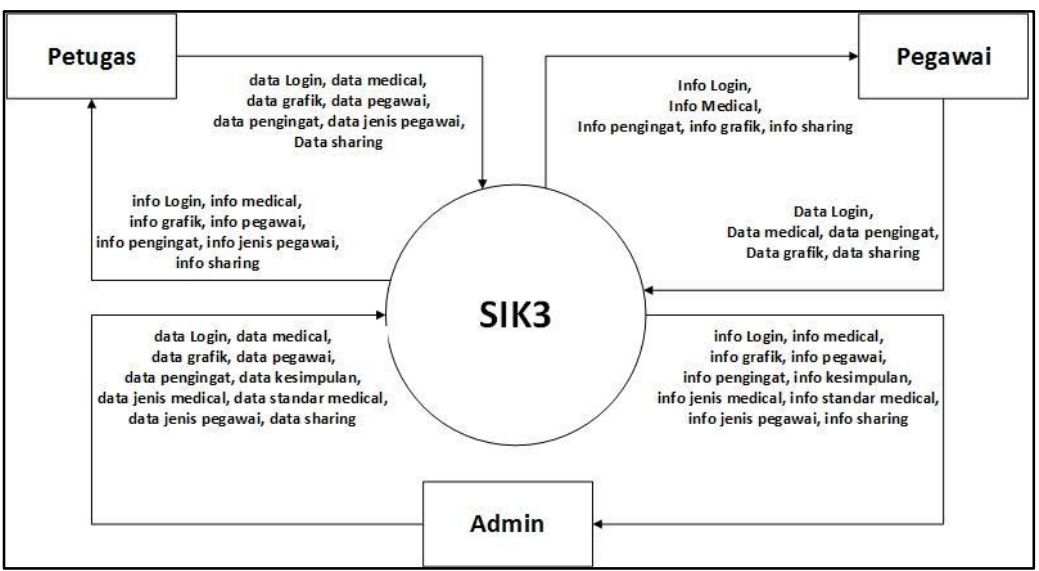

\subsection{Implementation}

Figure 5. Context diagram

\section{a. Login Page}

Implementation of the design Page Login can be seen in the image below. On viewing the page, login there are two textbox input username and password, wherein the interface design page login there is a form input the username and password the from a user and then there is a login button for submission, after which the user did submit the user will directly enter the appropriate page with the level.

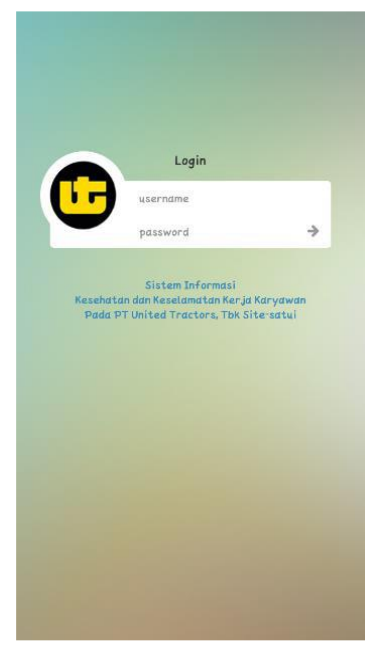

Figure 6. Login Page

\section{b. Dashboard page}

Figure 7 is a display of the implementation of the interface design for the home screen of the display page Mobile Phone, where on this homepage, you can view employee health data through tables and graphs. 


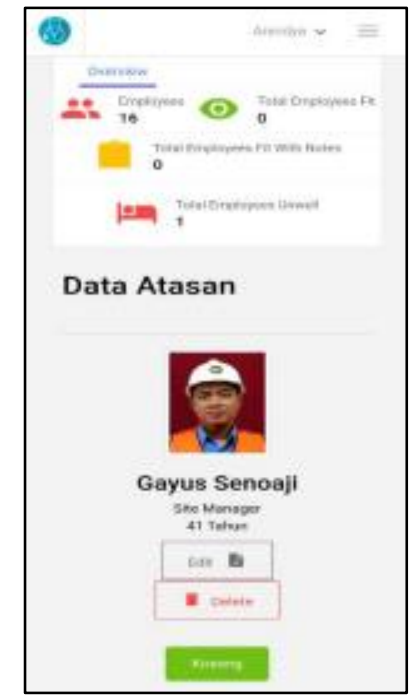

Figure 7. Employee Data Page

\section{c. Sharing Health Page}

Figure 9 is a display of the implementation design interface for the Sharing Health Media display. Display Mobile Phone, where on this page Sharing Health Media, you can view the data Sharing Health that is shared with all system users.

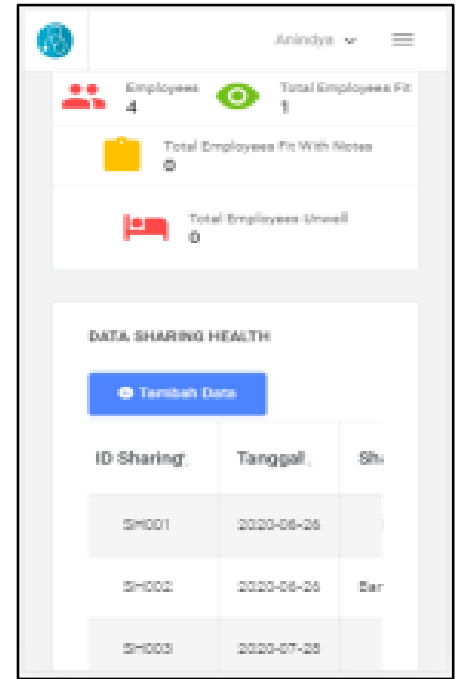

Figure 8. Sharing Health Page

\section{d. Automatic Reminder Page}

Figure 10 is a display implementation of the interface design for the Media Reminder Display. Display Mobile Phone, which can see data Reminder that is shared with all system users. 


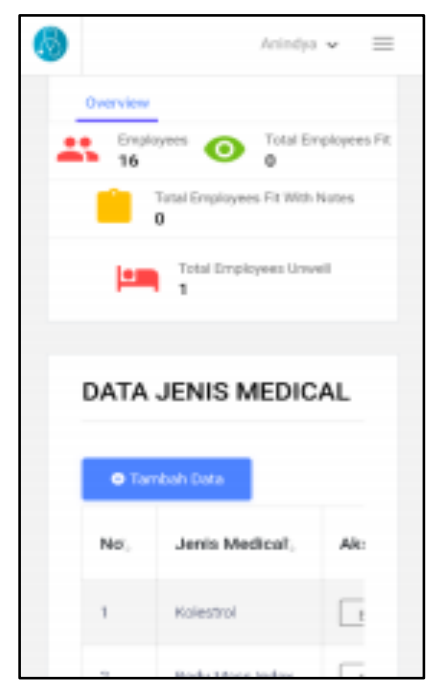

Figure 9. Automatic Reminder Page

\subsection{Testing System}

The testing system used by using Blackbox, here are the results of the testing system is done.

Table 1. Blackbox

\begin{tabular}{|c|l|l|c|}
\hline No. & \multicolumn{1}{|c|}{ Testing Scenario } & \multicolumn{1}{|c|}{ Expected Results } & Results \\
\hline 1. & Login system & can both log in to the system & Valid \\
\hline 2. & $\begin{array}{c}\text { view } \text { chart data MCU } \\
\text { results }\end{array}$ & $\begin{array}{l}\text { can see MCU results graph data on the page } \\
\text { dashboard }\end{array}$ & Valid \\
\hline 3. & Viewing data Employees & can view Employee data. & Valid \\
\hline 4. & Adding employee data & $\begin{array}{l}\text { can add employee data, which data will enter } \\
\text { the database and appear on the Employee } \\
\text { data menu in the system }\end{array}$ & Valid \\
\hline 5. & Changing employee data & $\begin{array}{l}\text { can change Employee data, whose data will } \\
\text { be changed in the database and appear on the } \\
\text { Employee data menu in the system }\end{array}$ & Valid \\
\hline 6. & Deleting employee data & $\begin{array}{l}\text { can delete employee data, which data will be } \\
\text { deleted in the database. }\end{array}$ & Valid \\
\hline 7. & Viewdata Sharing Health & $\begin{array}{l}\text { can viewdata Sharing Health sent to } \text { email } \\
\text { employee }\end{array}$ & Valid \\
\hline 8. & Add Sharing Health & $\begin{array}{l}\text { data can add data Sharing Health, which data } \\
\text { will be entered into the database and appear } \\
\text { on the data menu Sharing Health on the } \\
\text { system and sent to } \text { email employee }\end{array}$ & Valid \\
\hline Health & $\begin{array}{l}\text { can delete data Sharing Health, which data } \\
\text { will be deleted in the database. }\end{array}$ & Valid \\
\hline
\end{tabular}




\begin{tabular}{|c|c|c|c|}
\hline 10. & Viewing reminder data & $\begin{array}{l}\text { can see reminder data sent to e-mails } \\
\text { employee automatically every week after } \\
\text { filling in the results of MCU }\end{array}$ & Valid \\
\hline 11. & Adding reminder data & $\begin{array}{l}\text { can add reminder data whose data will be } \\
\text { entered into the database and appear on the } \\
\text { reminder data menu in the system and sent to } \\
\text { email employee automatically every week } \\
\text { after filling in the results of MCU }\end{array}$ & valid \\
\hline 12. & Deleting data reminders & $\begin{array}{l}\text { can delete reminder data, which data will be } \\
\text { deleted in the database. }\end{array}$ & Valid \\
\hline 13. & Viewing medical type data & can see medical type data that is added & Valid \\
\hline 14. & $\begin{array}{l}\text { Viewing data on employee } \\
\text { types }\end{array}$ & $\begin{array}{l}\text { can see data on employee types that are } \\
\text { added }\end{array}$ & Valid \\
\hline 15. & $\begin{array}{l}\text { Seeing medical conclusion } \\
\text { data }\end{array}$ & can see medical conclusion data added & Valid \\
\hline 16. & $\begin{array}{l}\text { Adding data medical } \\
\text { conclusion }\end{array}$ & $\begin{array}{l}\text { can add medical conclusion data, which data } \\
\text { will enter the database and appear on the } \\
\text { medical conclusion data menu }\end{array}$ & Valid \\
\hline 17. & $\begin{array}{l}\text { Changing data medical } \\
\text { conclusion }\end{array}$ & $\begin{array}{l}\text { can change medical conclusion data whose } \\
\text { data will be changed in the database and } \\
\text { appear in the medical conclusion data menu. }\end{array}$ & Valid \\
\hline 18. & $\begin{array}{l}\text { Deleting data medical } \\
\text { conclusion }\end{array}$ & $\begin{array}{l}\text { can delete medical conclusion data whose } \\
\text { data will be deleted in the database. }\end{array}$ & Valid \\
\hline 19. & Viewing employee data & can see employee data that is added & Valid \\
\hline 20. & Adding employee data & $\begin{array}{l}\text { can add employee data, whose data will be } \\
\text { entered into the database and appear on the } \\
\text { employee data menu. }\end{array}$ & Valid \\
\hline 21. & $\begin{array}{l}\text { Viewing medical data } \\
\text { employee }\end{array}$ & can see employee medical data added & Valid \\
\hline 22. & $\begin{array}{l}\text { Adding employee } \\
\text { medical data }\end{array}$ & $\begin{array}{l}\text { can add employee medical data, the data will } \\
\text { be entered into the database and appear on } \\
\text { the employee medical data menu }\end{array}$ & Valid \\
\hline 23. & $\begin{array}{l}\text { Printing medical data } \\
\text { Employees }\end{array}$ & $\begin{array}{l}\text { can print employee medical data whose data } \\
\text { will be printed according to the date entered. }\end{array}$ & Valid \\
\hline 24. & logout from system & can logout from system & Valid \\
\hline 25. & View condition data & can see employee condition & Valid \\
\hline
\end{tabular}

\section{CONCLUSION}

Based on the results and discussion of the final that has been carried out, it can be concluded, in making this system there are several stages, including data collection, development prototype, to application development which includes making Entity Relationship Diagram (ERD), Data Flow Diagrams (DFD), Flowcharts, Design Interface, implementation Interface, and system testing. Making this system using the PHP programming language with MySQL as the database and Website 2 APK Builder Pro 3.4.0 as a converter into 
an application that can be installed on the android smartphone of each employee at PT United Tractors Tbk, Site Satui.

\section{ACKNOWLEDGEMENTS}

The researcher would like to express his gratitude to Allah subhanahu wa ta'ala for his blessings, love, opportunity, health, and grace for completing this thesis.

Salawat was also sent to the Prophet Muhammad sallallaahu 'alaihi wa sallam who had conveyed the truth to mankind in general and Muslims in particular.

In the preparation of this journal, many parties have provided motivation, advice, support, and even remarks that are very helpful for researchers. In this valuable opportunity, the researcher would like to express his gratitude and appreciation to all of them. First, the deepest appreciation from researchers is given to beloved parents,

The researcher expressed his sincere appreciation to Mr. Agustian Noor M.Kom, and Mr. Khairul Anwar Hafizd, M.Kom as a supervisor and all lecturers in the information technology department, who has provided advice and motivation and taught him about discipline. Then to Mr. Muhammad Ghalih S.I.Kom., M.Sc, who has helped patiently complete this journal by providing suggestions, directions, and corrections from the beginning of the manuscript to completion, and for friends who encourage researchers

\section{REFERENCES}

[1] Y. A. Djawad, S. Suhaeb, Ridwansyah, H. Jaya, Fathahillah, and Saharuddin, "Development of an Intelligent Mobile Health Monitoring System for the Health Surveillance System in Indonesia," Irbm, vol. 42, no. 1, pp. 28-34, 2021, doi: 10.1016/j.irbm.2020.10.001.

[2] E. Adaku, N. A. Ankrah, and I. E. Ndekugri, "Design for occupational safety and health: A theoretical framework for organisational capability," Saf. Sci., vol. 133, no. August 2020, p. 105005, 2021, doi: 10.1016/j.ssci.2020.105005.

[3] M. Zhang, R. Shi, and Z. Yang, "A critical review of vision-based occupational health and safety monitoring of construction site workers,” Saf. Sci., vol. 126, no. July 2019, p. 104658, 2020, doi: 10.1016/j.ssci.2020.104658.

[4] E. Furnariandika, R. Sandora, and A. Khumaidi, "PEMBUATAN SISTEM INFORMASI REMINDER SERTIFIKASI PERALATAN DAN INSTRUMEN K3 BERBASIS WEBSITE PADA PERUSAHAAN PEMBANGKIT,” no. 2581, pp. 267-274.

[5] Z. Ji, D. J. Pons, and J. Pearse, "Integrating occupational health and safety into plant simulation," Saf. Sci., vol. 130, no. April, p. 104898, 2020, doi: 10.1016/j.ssci.2020.104898.

[6] E. Osei and T. P. Mashamba-Thompson, "Heliyon Mobile health applications for disease screening and treatment support in Low-and Middle-Income Countries: A Narrative Review Mobile health applications for disease screening and treatment support in Low-and Middle-Income Countries: A Narrative Re," Heliyon, vol. 7, no. March, p. e06639, 2021, doi: 10.1016/j.heliyon.2021.e06639.

[7] S. M and A. S. Rosa, Rekayasa Perangkat Lunak Terstruktur dan Berorientasi Objek. Bandung: Informatika, 2018.

[8] N. Mäkitalo et al., "Action-Oriented Programming Model: Collective Executions and Interactions in the Fog," $J$. Syst. Softw., vol. 157, 2019, doi: 10.1016/j.jss.2019.110391.

[9] C. O. Truică, E. S. Apostol, J. Darmont, and T. B. Pedersen, "The Forgotten Document-Oriented Database Management Systems: An Overview and Benchmark of Native XML DODBMSes in Comparison with JSON DODBMSes," Big Data Res., vol. 25, 2021, doi: 10.1016/j.bdr.2021.100205.

[10] K. Bail, E. Merrick, B. Redley, J. Gibson, R. Davey, and M. Currie, “'Blind leading the blind': Qualitative evaluation of unanticipated difficulties during nurse testing of a hospital health information system," Collegian, vol. 27, no. 1, pp. 82-88, 2020, doi: 10.1016/j.colegn.2019.03.004.

[11] J. L. Harrington, "Using CASE Tools for Database Design," Relational Database Des. Implement., pp. 215-230, 2016, doi: 10.1016/b978-0-12-804399-8.00012-0.

[12] M. Abdellatif et al., "A taxonomy of service identification approaches for legacy software systems modernization,” J. Syst. Softw., vol. 173, p. 110868, 2021, doi: 10.1016/j.jss.2020.110868.

\section{BIOGRAPHIES OF AUTHORS}




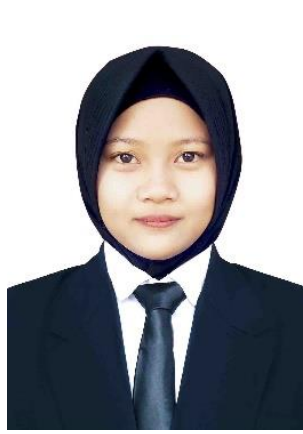

Maya Gian Sister. Currently, she has completed her Diploma 3 education in the Information Technology Department at Poliliteknik Negeri Tanah Laut.

Email: mayagiansister@gmail.com

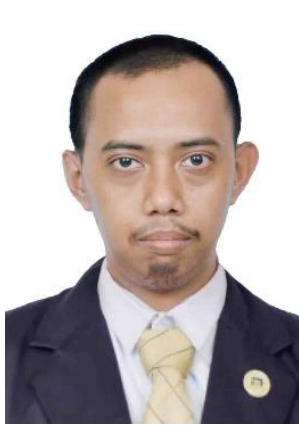

Agustian Noor, M.Kom, completed a degree S.Kom in the Department of Informatics at Uniska Banjarmasin, South Kalimantan, and completed a master's degree in the Department of Informatics at Dian Nuswantoro University, Semarang, Central Java. is currently a lecturer in Information Technology at Politeknik Negeri Tanah Laut and is a Programmer and Analysis at InterMedia Solusindo.

Email: agustiannor@politala.ac.id

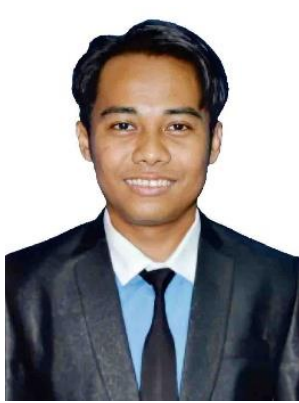

Khairul Anwar Hafizd, obtain a degree S.Kom in the field of Informatics, STTI 2011, then continued his bachelor's degree in the Department of Business Information Systems at LIKMI Bandung and obtained the M.Kom degree in 2014. As long as the authors take a Strata 2 education, the author focuses on examining the field of systems Information relating to the System Business Information. After obtaining a Master's degree, the author works as a lecturer in the engineering department Informatics, Politeknik Negeri Tanah Laut from 2015 until now. 